The Impact of Teacher Feedback on Students' Academic Performance: A Mediating Role of Self-efficacy

\title{
1Manzoor Ahmed ${ }^{2}$ Dr. Martin Thomas* ${ }^{3}$ Rimesha Farooq
}

1. Lecturer, Department of Education, Turbat University, Balochistan, Pakistan

2. Associate Professor, Department of Education, Forman Christian College, Lahore, Punjab, Pakistan

3. Lecturer, Department of Education, Forman Christian College (A Chartered University), Lahore, Punjab, Pakistan

\begin{tabular}{|c|c|}
\hline & \\
\hline & \multirow{3}{*}{$\begin{array}{l}\text { A teacher's constructive, evaluative and corrective feedback is } \\
\text { generally perceived as an essential ingredient for the students' } \\
\text { academic performance. It is also believed that self-efficacy } \\
\text { contributes as a mediator between a teacher's feedback and } \\
\text { students' academic performance. The present study was conducted } \\
\text { to find the impact of the teachers' constructive, corrective, and } \\
\text { evaluative feedback on students' academic performance with self- } \\
\text { efficacy as a mediator. By utilizing the stratified sampling technique, } \\
\text { data was gathered through a structured questionnaire from } 336 \\
\text { sample cases of the Bachelor of Science (BS) and the Bachelor of } \\
\text { Education, Honors (B. Ed, Hons) batches of the higher education } \\
\text { institutes in Turbat, Pakistan. The findings revealed that the } \\
\text { teachers' constructive, corrective, and evaluative feedback have } \\
\text { significant effect on students' academic performance. Furthermore, } \\
\text { the results also indicate that students' self-efficacy has a significant } \\
\text { mediating effect between the teachers' constructive and evaluative } \\
\text { feedback and students' academic performance. }\end{array}$} \\
\hline & \\
\hline & \\
\hline
\end{tabular}

\section{Introduction}

A teacher's feedback is considered an essential component of teaching and learning process that motivates the students and provides them with the direction to achieve high level of academic performance (Mandhane, Ansari \& Shaikh, 2015). The constructive feedback provides awareness and facilitates students to identify their areas for further improvement and encourages them to enhance their practices and efforts towards learning and teaching activities. However, Hamid and Mahmood (2010) contend that there is limited knowledge on the concept of constructive feedback process and its importance in Pakistani educational institutions. Furthermore, Kashif, Rahman, Mustafa and Basharat (2014) explored that a teacher's evaluative feedback is not paid much attention in the field of education in under developing countries like Pakistan. Hafeez and Wahaja (2014) have claimed that corrective feedback is not taken under consideration in Pakistan's ongoing educational system. Written feedback is used as a tool of guideline to improve students' work without discussing the identified mistakes and errors in the assigned assignments. 
Teachers' constructive, evaluative, and corrective feedback components enhance students' self-efficacy and academic performance in the field of education (Donche, Coertjens, Vanthournout, Petegem, 2012; Chandler, 2003; Oluwatayo and Fatoba, 2010). Constructive feedback for example is considered a contributing factor towards students' academic improvement (Toit, 2012), essential factor for effective learning (Omer \& Abularhim, 2017), a meaningful tool for academic performance (Ovando, 1994) that increases the students' self-efficacy (Donche, et al. (2012). Duffy (2013) explains that students often feel difficulties in getting constructive feedback from their teachers due to the inconsistency of the amount of feedback, feedback type and its given timing. Aston and Hallam (2011) assert that providing effective constructive feedback needs consideration, deep insight, and delicacy. Hattie and Timperley (2007) have explored that teacher's verbal and written evaluative feedback is one of the most powerful, immediate, and direct responses that is used by teachers to raise the students learning, improve their motivational level and academic performance in a classroom setting. Evaluative feedback in summative or formative form has a significant influence on the students' sense of selfefficacy (Chan and Lam, 2010) and can boost students' academic performance (Oluwatayo \& Fatoba, 2017).

Regarding the corrective feedback, Ahmed, Saeed, and Salam (2013) explains that students who receive corrective feedback from their teachers, secure high scores in the exams, get better understanding of the concepts, participate actively, and perform well in the classroom activities. They further assert that students who receive corrective feedback from their teachers may also do the classroom assignment on time, communicate more effectively and share their views easily in the class discussions. Corrective feedback is one of the most widely used feedbacks all over the world that plays a vital role in enhancing students' academic performance (Chandler, 2003).

Through corrective feedback, teachers provide opportunities to their students to avoid repeating mistakes (Li, Schwabe, Yang and Chen, 2015). Wang and Wu (2017) believe that corrective feedback plays a crucial and beneficial role in contributing for the students' performance in the field of education. Similarly, according to Aravena (2015), providing corrective feedback to the students remains an essential part of the teachers' assessment procedure and students' learning always depends on corrective feedback from their teachers. In addition, Meral, Colak, Zereyak (2012) found a significant relationship between self-efficacy and the students' academic performance. Ahmed and Safaria (2013) claim that students with high self-efficacy score higher marks in their tests and exams and may choose complex courses to study in the future.

Furthermore, in a study conducted by Honicke and Broadbent (2016), it is proved that self-efficacy is mediatory correlated with academic performance in higher education level. Tiyuri et al. (2018) concluded that self-efficacy and academic performance are directly correlated with each other. Previously, Karl et al, (1993) claimed that students' selfefficacy can be increased by providing them feedback of their academic performance. For example, teachers' feedback, that is based on the sources of self-efficacy beliefs directly affect the students' self-efficacy beliefs and their performance (Akkuzu, 2014). Cervelló, Escarti and Guzman (2007) consider self-efficacy as a cognitive variable that plays a vital role to mediate the relationship of feedback and academic performance. Wang and $\mathrm{Wu}$ (2008) asserts that feedback that students receive from their teachers in various forms 
including constructive, evaluate, corrective can enhance their self-efficacy and learning performance.

The present study further highlights the impact of teachers' constructive, evaluative and corrective feedback on undergraduate students' academic performance in higher educational level in District Kech, Balochistan when their self-efficacy performs a mediating role.

\section{Theoretical Background}

The current research is supported by social cognition theory. Bandura (2001) highlights that social cognition theory pays attention on interactions among personal influences, behavioral and environmental factors and also emphasizes that people are selforganizing, proactive, self-regulating and self-reflecting. Thus self-efficacy is the major feature of this theory. Bandura (1982) defined self-efficacy as a belief in the ability of an individual to perform tasks. Sources of self-efficacy are derived from enactive mastery (performance outcomes), vicarious experience (ex. self-modeling), verbal persuasion (ex. verbal encouragement), and physiological arousal (ex. emotional state). Mastery experiences are one of the most powerful sources of self-efficacy in the process of teaching and learning (Bandura 1997). Generally, students are enactive students. They learn specific tasks by carrying out those particular tasks while they are provided with feedback about their performance. Furthermore, verbal or social persuasion that can be provided through constructive, corrective and evaluative feedback enhances students' self-efficacy and academic performance (Wang \& Wu, 2008). This supports earlier study by Glickman (2002) who found that students who receive verbal feedback show the abilities to get mastery in the given activities.

\section{Literature Review}

\section{Constructive feedback, self-efficacy and students' academic performance}

Omer and Abdularhim (2017) explored that constructive feedback is an important ingredient of effective learning. Nyiramana (2017) proved that the provision of constructive feedback becomes useful to improve the process of teaching and learning. It enhances pedagogical relationship of the teachers with their students' motivational level and self-regulated learning process that supports them to improve their academic performance.

According to Toit (2012), students who receive constructive feedback, focus on the level of their assigned tasks better and can improve their academic performance. Duffy (2013) identified that teachers are responsible for giving regular constructive feedback to their students to ensure that they are meeting and achieving their target learning objectives. Aston and Hallam (2010) claims that students can not improve if their teachers or instructors do not give them accurate and constructive feedback regarding their learning competency and academic progress. The quantitative study identified that students prefer external feedback sources to receive information about their learning and as well as the internal feedback sources for self-development. The findings showed that the sense of selfefficacy and the way of regulating own learning of the students are associated with these external and internal constructive feedback. Koseoglu (2015) study showed that students with high self-efficacy achieve high academic scores and have the ability to analyze and 
control the challenges which they faced during learning process. Hence, the present study investigates and hypothesizes:

H1 (a): Constructive feedback significantly affects students' Academic Performance

H1 (b): Self-efficacy significantly mediates the relationship between constrictive feedback and academic performance

\section{Corrective feedback, self-efficacy and students' performance}

Sermsook, Liamnimitr and Pochakorn (2017) concluded that corrective feedback either in the form of written or verbal is more beneficial for rectifying students' academic errors. Srichanyachon (2012) found that direct feedback is more beneficial and useful for the correction of students' errors at the beginner level as they can use the correct form immediately as given by their teachers. Sarvestani and Pishker (2015) found that verbal corrective feedback helps students create better understanding in the process of targeted learning grammatical features and it is also concluded that such feedback can reinforce long-term memory of these learned features. However, indirect feedback enables students to self-repair their errors that they commit in the processes of performing tasks (Erlam, Ellis \& Batstone, 2013). In addition, Jamalinesari, Rahimi, Gowhary and Azizifar (2015) confirmed that corrective feedback from teachers promote an encouraging environment for writing and learning. Hence, Westmacott (2017) claim that indirect corrective feedback has a stronger positive effect on students' learning autonomy as compared to direct corrective feedback.

Ahmad and Safaria (2013) found that student who receive corrective feedback from their teachers secure high scores in the exams, understand the concepts deeply, participate, and perform actively in the classroom activities, do classroom assignment on time, communicate effectively, and share their views easily in class discussions. Pham (2015) found that corrective feedback does not only help students improve learning tasks, but it develops their ideas and confidence level. Arbabisarjou, Zare, Shahrakipour and Ghoreishinia (2016) in their study found that students with high self-efficacy have more optimal academic performance and status as compared to the students with low selfefficacy. It is concluded that there is a direct positive significant relationship between students' academic performance and self-efficacy.

Schunk and Zimmerman (2007) mentioned that teachers' feedback support students to find and point out corrective measures and also help them find valid information to remedy troublesome of the problematic aspects of the tasks. Furthermore, Schunk and Zimmerman (2007) examined that correction of students' mistakes and errors by their teachers' support help them get success in learning and a successful learning enhance their self-efficacy. Hence, the present study developed the following hypotheses:

H2 (a): Corrective feedback significantly affects students' Academic Performance

H2 (b): Self-efficacy significantly mediates the relationship between corrective feedback and academic performance 


\section{Evaluative feedback, self-efficacy and students' performance}

Oluwatayo and Fatoba (2010) examined that students who receive evaluative feedback can perform better as compared to those who do not receive evaluative feedback from their teachers. Ran and Danli (2016) explored that evaluative feedback is more dominant than other types of feedback in the process of teaching and learning. Mueller and Dweck (1998) claims that evaluative feedback provides the opportunity to improve the students' learning out-comes.

Dupret (2016) found that the students who receive feedback from their instructors become more efficacious about their learning ability and can perform their assigned tasks in a better way as they are exposed to the assigned tasks is an encouraging environment. According to Mehregan and Seresht (2014), teachers have the abilities and capabilities to direct their students towards various academic and attainment goals by using and utilizing evaluative feedback.

Chan and Lam (2010) investigated that teachers use various ways to perform evaluative feedback during teaching and learning process to influence the self-efficacy of the students. However, Dogan (2015) described that students' self-efficacy is the strongest predictor of students' academic performance.

Hence, the current research examines the following hypothesizes.

H3 (a): Evaluative feedback significantly affects students' Academic Performance

H3 (b): Self-efficacy significantly mediates between Evaluative feedback and academic performance

\section{Conceptual Framework of the Current Research}

From the literature review, the following conceptual was developed

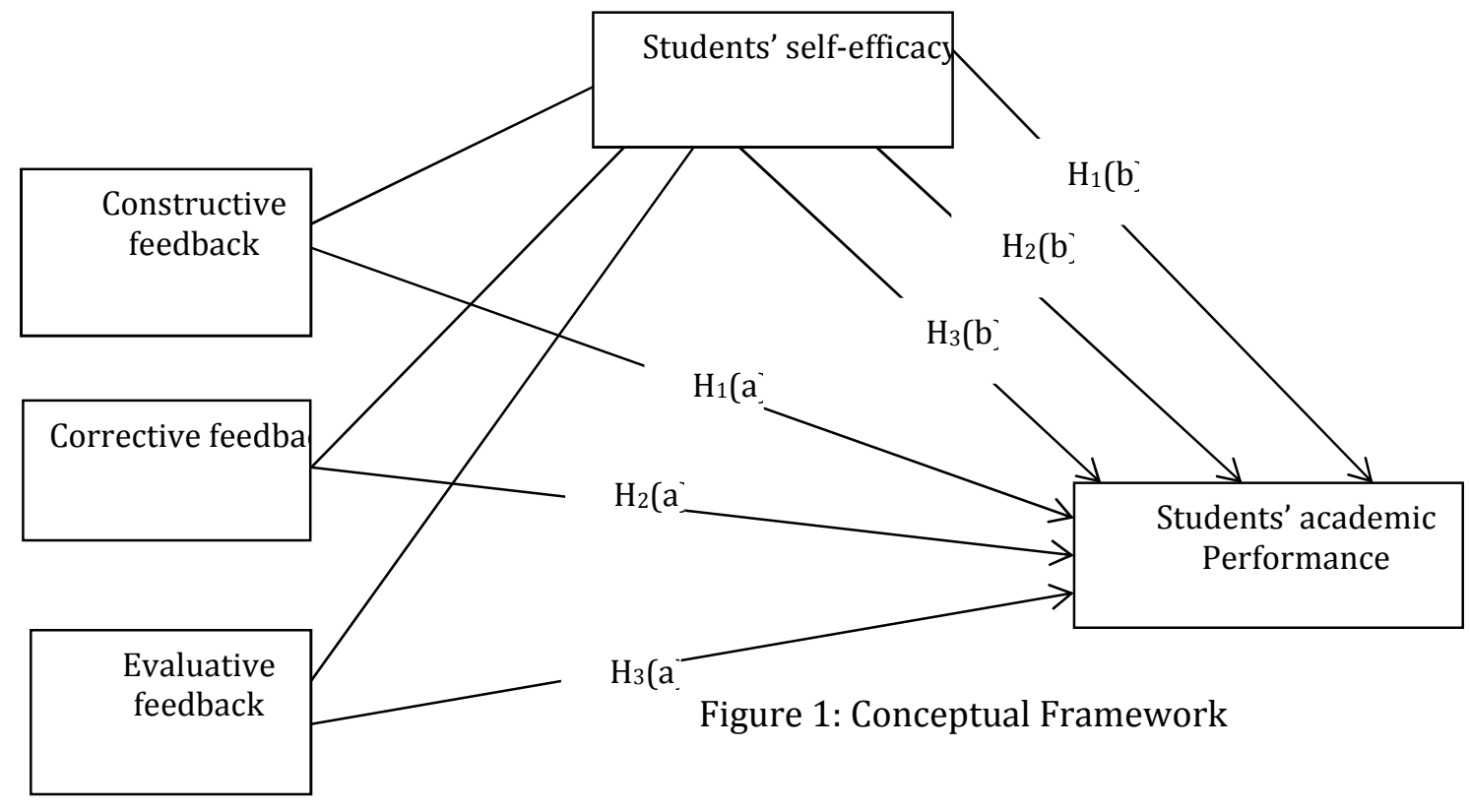




\section{Material and Methods}

In this quantitative research, stratified random sampling technique was used to divide the research population into separate strata and to select the samples. Population of the present study was comprised of undergraduate level students enrolled in public higher education institution of District Turbat. A sample of 336 out of 842 Bachelor of Science (BS) and Bachelor of Education (B.Ed) undergraduate students were selected from different BS and B. Ed programs in the entire district. The closed ended questionnaire (Refer to Appendix A), having 09 items concerning constructive feedback, 09 items concerning corrective feedback, 11 items for evaluative feedback, 08 items representing students' self-efficacy and 08 items representing students' academic performance. Reliability of the research instrument was established through inter-coder reliability and pilot testing that was completed prior to the main study. The research data was analyzed through the Smart-PLS SEM.

Data Analysis and Testing of Hypotheses

\section{Demographic Details}

Table 1

Respondents' Descriptive Information

\begin{tabular}{llll}
\hline & & Frequency & Percent \\
\hline Gender & Male & 189 & 57.3 \\
\hline & Female & 141 & 42.7 \\
\hline Total & 330 & 100.0 \\
\hline & $18-21$ & 189 & 57.3 \\
\hline & $22-25$ & 94 & 28.5 \\
\hline & $26-29$ & 6 & 1.8 \\
\hline & $30-33$ & 2 & .6 \\
\hline & Sub Total & 291 & 88.2 \\
\hline Memester vise & Missing & 39 & 11.8 \\
\hline Distribution & B.Ed(Hons) & 330 & 100.0 \\
\hline & BS(Balochi) & 81 & 24.5 \\
\hline & BBA & 24 & 7.3 \\
\hline & BS(English) & 49 & 14.8 \\
\hline & BS(Chemistry) & 28 & 8.5 \\
\hline & BS(Economics) & 42 & 12.7 \\
\hline & BS(Commerce) & 8 & 10.9 \\
\hline & BS(Political Sciences) & 19 & 2.4 \\
\hline & BSCS & 5.8 \\
\hline Tomester vise & Total & 43 & 13.0 \\
\hline Distribution & 4th & 330 & 100.0 \\
\hline & & 165 & 50.0 \\
\hline
\end{tabular}




\begin{tabular}{llll}
\hline $6^{\text {th }}$ & 32 & 9.7 \\
\hline $8^{\text {th }}$ & 20 & 6.1 \\
\hline Total & 330 & 100.0 \\
\hline
\end{tabular}

All students are enrolled in four years undergraduate programs.

Table 1 indicates that out of total 330 respondents, 189 (57.27\%) were male and $141(42.73 \%)$ were female undergraduate students. They were in the 18 to 33 age bracket and were enrolled in various bachelor programs.

\section{The Measurement Model (Outer Model)}

In order to establish adequate validity and reliability of the measurement model, content validity, convergent validity and discriminant validity were measured (Ahmed, Thomas \& Hamid, 2020). The content validity of the research model was established as the factor loadings above the threshold value (0.6) (Awang, Lim \& Zainudin, 2018) were retained (Refer to Table 2). The Cronbach's alpha as the lower boundary for internal consistency reliability was above 0.6 and the composite reliability as the upper boundary was above 0.7 for the internal consistency reliability (Hair, Ringle \& Sarstedt, 2013). Thus the construct reliability and validity of the current research was established (Refer to Table 3 ). As the factor loadings were above 0.6 (Refer to Table 2) and the value average variance extracted (AVE) were greater than 0.5 Hair, Risher, Sarstedt \& Ringle, 2019) or close 0.5 (Hair, Rishe, Sarsted, \& Ringle, 2018), the convergent validity of the current research was maintained (Refer to Table 3).

Table 2

Outer Loading

\begin{tabular}{|c|c|c|c|c|c|}
\hline & $\begin{array}{l}\text { Academic } \\
\text { Performanc } \\
\text { e (DV) }\end{array}$ & $\begin{array}{l}\text { Constructive } \\
\text { Feedback (IV) }\end{array}$ & $\begin{array}{l}\text { Corrective } \\
\text { Feedback (IV) }\end{array}$ & $\begin{array}{l}\text { Evaluative } \\
\text { Feedback (IV) }\end{array}$ & $\begin{array}{l}\text { Self- } \\
\text { Efficacy } \\
(\mathrm{MV})\end{array}$ \\
\hline $\mathrm{AP}$ & 0.680 & & & & \\
\hline $\mathrm{AP}$ & 0.790 & & & & \\
\hline $\mathrm{AP}$ & 0.731 & & & & \\
\hline $\mathrm{AP}$ & 0.696 & & & & \\
\hline $\mathrm{AP}$ & 0.708 & & & & \\
\hline $\mathrm{CF}$ & & 0.708 & & & \\
\hline $\mathrm{CF}$ & & 0.726 & & & \\
\hline $\mathrm{CF}$ & & 0.716 & & & \\
\hline $\mathrm{CF}$ & & 0.734 & & & \\
\hline CRF & & & 0.620 & & \\
\hline CRF & & & 0.652 & & \\
\hline CRF & & & 0.773 & & \\
\hline CRF & & & 0.697 & & \\
\hline $\mathrm{EF}$ & & & & 0.711 & \\
\hline $\mathrm{EF}$ & & & & 0.653 & \\
\hline $\mathrm{EF}$ & & & & 0.717 & \\
\hline EF & & & & 0.726 & \\
\hline SE & & & & & 0.712 \\
\hline SE & & & & & 0.720 \\
\hline
\end{tabular}




\begin{tabular}{ll}
\hline SE & 0.717 \\
\hline SE & 0.689 \\
\hline
\end{tabular}

Table 3

Construct Reliability

\begin{tabular}{llll}
\hline & $\begin{array}{l}\text { Cronbach's } \\
\text { Alpha }\end{array}$ & $\begin{array}{l}\text { Composite } \\
\text { Reliability }\end{array}$ & $\begin{array}{l}\text { Average } \\
\text { Extracted (AVE) }\end{array}$ \\
\hline Academic Performance (DV) & 0.770 & 0.844 & 0.521 \\
\hline Constructive Feedback (IV) & 0.693 & 0.812 & 0.520 \\
\hline Corrective Feedback (IV) & 0.625 & 0.781 & 0.473 \\
\hline Evaluative Feedback (IV) & 0.658 & 0.795 & 0.493 \\
\hline Self-Efficacy (MV) & 0.672 & 0.802 & 0.503 \\
\hline
\end{tabular}

To ensure that a set of items can discriminate a factor from other factors, three results were assessed. Firstly, during cross loadings, all items strongly loaded against their respective factor (Refer to Table 4) when compared with cross loadings in rows and columns (Fornell \& Larcker, 1981). Secondly, all diagonal bold values of the factors (Refer to Table 5), representing square roots of their respective AVE are greater than the values in their respective rows and columns (Fornell \& Larcker, 1981). Thirdly, all values of Heterotrait-Monotrait (HTMT) ratios are $<1$ or not greater than 0.9 (Gold, Malhotra \& Segars, 2001) (Refer to Table 6). Thus the null hypothesis $\left(\mathrm{H}_{0}\right.$ : HTMT $\geq 1$ ) was rejected (Henseler, Ringle \& Sarstedt, 2015). This depicts that all factors discriminate from each other (Hair et al, 2018).

Table 4

Cross Loadings

\begin{tabular}{llllll}
\hline & $\begin{array}{l}\text { Academic } \\
\text { Performance } \\
\text { (DV) }\end{array}$ & $\begin{array}{l}\text { Constructive } \\
\text { Feedback (IV) }\end{array}$ & $\begin{array}{l}\text { Corrective } \\
\text { Feedback (IV) }\end{array}$ & $\begin{array}{l}\text { Evaluative } \\
\text { Feedback (IV) }\end{array}$ & $\begin{array}{l}\text { Self- } \\
\text { Efficacy } \\
\text { (MV) }\end{array}$ \\
\hline AP & $\mathbf{0 . 6 8 0}$ & 0.290 & 0.304 & 0.307 & 0.395 \\
\hline AP & $\mathbf{0 . 7 9 0}$ & 0.293 & 0.354 & 0.415 & 0.442 \\
\hline AP & $\mathbf{0 . 7 3 1}$ & 0.369 & 0.313 & 0.375 & 0.479 \\
\hline AP & $\mathbf{0 . 6 9 6}$ & 0.320 & 0.293 & 0.404 & 0.440 \\
\hline AP & $\mathbf{0 . 7 0 8}$ & 0.418 & 0.449 & 0.414 & 0.441 \\
\hline CF & 0.336 & $\mathbf{0 . 7 0 8}$ & 0.356 & 0.303 & 0.280 \\
\hline CF & 0.325 & $\mathbf{0 . 7 2 6}$ & 0.387 & 0.376 & 0.347 \\
\hline CF & 0.331 & $\mathbf{0 . 7 1 6}$ & 0.358 & 0.305 & 0.362 \\
\hline CF & 0.367 & $\mathbf{0 . 7 3 4}$ & 0.465 & 0.349 & 0.382 \\
\hline CRF & 0.338 & 0.326 & $\mathbf{0 . 6 2 0}$ & 0.340 & 0.305 \\
\hline CRF & 0.309 & 0.279 & $\mathbf{0 . 6 5 2}$ & 0.328 & 0.259 \\
\hline CRF & 0.354 & 0.428 & $\mathbf{0 . 7 7 3}$ & 0.445 & 0.316 \\
\hline CRF & 0.308 & 0.462 & $\mathbf{0 . 6 9 7}$ & 0.439 & 0.275 \\
\hline EF & 0.381 & 0.284 & 0.339 & $\mathbf{0 . 7 1 1}$ & 0.364 \\
\hline EF & 0.351 & 0.381 & 0.457 & $\mathbf{0 . 6 5 3}$ & 0.373 \\
\hline EF & 0.437 & 0.322 & 0.436 & $\mathbf{0 . 7 1 7}$ & 0.363 \\
\hline & & & & & \\
\hline
\end{tabular}




\begin{tabular}{llllll}
\hline EF & 0.315 & 0.311 & 0.349 & $\mathbf{0 . 7 2 6}$ & 0.311 \\
\hline SE & 0.470 & 0.340 & 0.322 & 0.393 & $\mathbf{0 . 7 1 2}$ \\
\hline SE & 0.433 & 0.329 & 0.373 & 0.404 & $\mathbf{0 . 7 2 0}$ \\
\hline SE & 0.387 & 0.326 & 0.255 & 0.344 & $\mathbf{0 . 7 1 7}$ \\
\hline SE & 0.436 & 0.362 & 0.239 & 0.286 & $\mathbf{0 . 6 8 9}$ \\
\hline
\end{tabular}

Table 5

Fornell-Larcker Criterion

\begin{tabular}{llllll}
\hline & $\begin{array}{l}\text { Academic } \\
\text { Performance } \\
\text { (DV) }\end{array}$ & $\begin{array}{l}\text { Constructive } \\
\text { Feedback (IV) }\end{array}$ & $\begin{array}{l}\text { Corrective } \\
\text { Feedback } \\
\text { (IV) }\end{array}$ & $\begin{array}{l}\text { Evaluative } \\
\text { Feedback } \\
\text { (IV) }\end{array}$ & $\begin{array}{l}\text { Self- } \\
\text { Efficacy } \\
\text { (MV) }\end{array}$ \\
\hline $\begin{array}{l}\text { Academic } \\
\text { Performance } \\
\text { (DV) }\end{array}$ & $\mathbf{0 . 7 2 2}$ & & & & \\
\hline $\begin{array}{l}\text { Constructive } \\
\text { Feedback (IV) }\end{array}$ & 0.472 & $\mathbf{0 . 7 2 1}$ & & & \\
\hline $\begin{array}{l}\text { Corrective } \\
\text { Feedback (IV) }\end{array}$ & 0.478 & 0.546 & $\mathbf{0 . 6 8 8}$ & & \\
\hline $\begin{array}{l}\text { Evaluative } \\
\text { Feedback (IV) }\end{array}$ & 0.534 & 0.463 & 0.567 & $\mathbf{0 . 7 0 2}$ & \\
\hline $\begin{array}{l}\text { Self-Efficacy } \\
\text { (MV) }\end{array}$ & 0.610 & 0.478 & 0.422 & 0.505 & $\mathbf{0 . 7 0 9}$ \\
\hline
\end{tabular}

Table 6

Heterotrait-Monotrait Ratio (HTMT)

\begin{tabular}{llllll}
\hline & $\begin{array}{l}\text { Academic } \\
\text { Performance } \\
\text { (DV) }\end{array}$ & $\begin{array}{l}\text { Constructive } \\
\text { Feedback (IV) }\end{array}$ & $\begin{array}{l}\text { Corrective } \\
\text { Feedback } \\
\text { (IV) }\end{array}$ & $\begin{array}{l}\text { Evaluative } \\
\text { Feedback } \\
\text { (IV) }\end{array}$ & $\begin{array}{l}\text { Self- } \\
\text { Efficacy } \\
\text { (MV) }\end{array}$ \\
\hline $\begin{array}{l}\text { Academic } \\
\text { Performance } \\
\text { (DV) }\end{array}$ & & & & \\
\hline $\begin{array}{l}\text { Constructive } \\
\text { Feedback (IV) }\end{array}$ & 0.640 & 0.823 & & \\
\hline $\begin{array}{l}\text { Corrective } \\
\text { Feedback (IV) }\end{array}$ & 0.684 & 0.683 & 0.876 & \\
\hline $\begin{array}{l}\text { Evaluative } \\
\text { Feedback (IV) }\end{array}$ & 0.737 & 0.696 & 0.644 & 0.751 & \\
\hline $\begin{array}{l}\text { Self-Efficacy } \\
\text { (MV) }\end{array}$ & 0.843 & & & \\
\hline
\end{tabular}

\section{The Structural Model and Hypothesis Testing}

The suggested hypotheses of the current research were tested through Partial Least Squares - Structural Equation Modeling (PLS-SEM) in SmartPLS (Ringle, Wende, \& Becker, 2015) (Ringle et al., 2015). Table 6 indicates that constructive feedback $(t=3.058, p=$ 
0.002), corrective feedback $(\mathrm{t}=2.785, \mathrm{p}=0.005)$ and evaluative feedback $(\mathrm{t}=5.979, \mathrm{p}=$ 0.001 ) have a significant effect on students' academic performance. Thus three hypotheses $\mathrm{H}_{1}(\mathrm{a}), \mathrm{H}_{2}(\mathrm{a})$ and $\mathrm{H}_{3}(\mathrm{a})$ were supported.

Table 7 presents mediation analysis for the current research. The table indicates that students' self-efficacy significantly mediates the effect of constructive feedback $(t=$ $3.902, p=0.001)$ and evaluative feedback $(t=5.150, p=0.001)$ on students' academic performance. Thus the hypotheses $\mathrm{H}_{1}$ (b) and $\mathrm{H}_{3}$ (b) were supported. Self-efficacy does not significantly mediate the effect of corrective feedback on students' academic performance $\left(t=1.097, p=0.273\right.$ ). Thus $\mathrm{H}_{2}$ (b) was not supported (Refer to Table 7).

Table 6

Hypothesis Testing

\begin{tabular}{|c|c|c|c|c|c|c|c|}
\hline Hypothesis & Relationship & $\begin{array}{l}\text { Original } \\
\text { Sample(0) }\end{array}$ & $\begin{array}{l}\text { Sample } \\
\text { Mean (M) }\end{array}$ & S.D & $\begin{array}{l}\mathrm{T} \\
\text { Statistics }\end{array}$ & $P$ Values & Decision \\
\hline $\mathrm{H}_{1}(\mathrm{a})$ & $\begin{array}{l}\text { Constructive } \\
\text { Feedback (IV) -> } \\
\text { Academic } \\
\text { Performance } \\
\text { (DV) }\end{array}$ & 0.228 & 0.227 & 0.074 & 3.058 & 0.002 & Supported \\
\hline $\mathrm{H}_{2}(\mathrm{a})$ & $\begin{array}{l}\text { Corrective } \\
\text { Feedback (IV) -> } \\
\text { Academic } \\
\text { Performance } \\
\text { (DV) }\end{array}$ & 0.167 & 0.171 & 0.060 & 2.785 & 0.005 & Supported \\
\hline $\mathrm{H}_{3}(\mathrm{a})$ & $\begin{array}{l}\text { Evaluative } \\
\text { Feedback (IV) -> } \\
\text { Academic } \\
\text { Performance } \\
\text { (DV) }\end{array}$ & 0.338 & 0.341 & 0.056 & 5.979 & 0.000 & Supported \\
\hline
\end{tabular}

Table 7

Hypothesis Testing: Mediation Analysis

\begin{tabular}{|c|c|c|c|c|c|c|c|}
\hline $\begin{array}{l}\text { Hypoth } \\
\text { esis }\end{array}$ & Relationship & $\begin{array}{l}\text { Original } \\
\text { Sample } \\
(0)\end{array}$ & $\begin{array}{l}\text { Sample } \\
\text { Mean (M) }\end{array}$ & S.D & $\begin{array}{l}\mathrm{T} \\
\text { Statistics }\end{array}$ & P Value & Decision \\
\hline $\mathrm{H}_{1}(\mathrm{~b})$ & $\begin{array}{l}\text { Constructive Feedback } \\
\text { (IV) -> Self-Efficacy } \\
\text { (MV) }\end{array}$ & 0.281 & 0.283 & 0.072 & 3.902 & 0.000 & $\begin{array}{l}\text { Supporte } \\
\text { d }\end{array}$ \\
\hline $\mathrm{H}_{2}$ (b) & $\begin{array}{lr}\text { Corrective } & \text { Feedback } \\
(\mathrm{IV}){ }^{->} & \text {Self-Efficacy } \\
(\mathrm{MV}) & \\
\end{array}$ & 0.083 & 0.086 & 0.076 & 1.097 & 0.273 & $\begin{array}{l}\text { Not } \\
\text { supporte } \\
\text { d }\end{array}$ \\
\hline $\mathrm{H}_{3}(\mathrm{~b})$ & 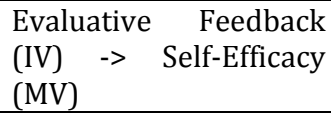 & 0.328 & 0.330 & 0.064 & 5.150 & 0.000 & $\begin{array}{l}\text { Supporte } \\
\text { d }\end{array}$ \\
\hline
\end{tabular}

\section{Discussion}

Statistical analyses of the variables as discussed above prove that teachers' constructive, corrective, and evaluative feedback play important role in developing students' academic performance. These hypotheses are similar to theoretical and empirical literatures of the past and recent studies and the result proves that $\mathrm{H}_{1}$ (a) constructive feedback (IV) and academic performance (DV) teachers' constructive feedback play a very 
important role for developing students' academic performance. This result is similar with previous studies conducted by Omer and Abdularhim (2017) and Duffy (2013). The result of $\mathrm{H}_{2}$ (a) corrective Feedback (IV) and academic performance (DV) was reported statistically significant as $(p=0.038)$. This result is in accordance with the results of previous researches of Ahmad and Safaria (2013) and Chandler (2003). Statistical relationship between $\mathrm{H}_{3}(\mathrm{a})$ evaluative feedback (IV) and academic performance $(\mathrm{p}=0.001)$ proves that the role of evaluative feedback is very crucial for enhancing students' academic performance in the field of education. This result supports the findings of Oluwatayo and Fatoba (2017) and Wilbert et al (2010).

In addition, statistically positive significance role of $\mathrm{H}_{1}$ (b) constructive feedback (IV), self-efficacy (MV) and academic performance (DV) has made this clear that the teachers' constructive feedback increases student's self-efficacy towards academic performance. The result of $\mathrm{H}_{1}$ (b) is supported by Albert Bandura (1997) and Donche et al. (2012) and Nyiramana (2017). Furthermore, the result of $\mathrm{H}_{3}$ (b) evaluative feedback (IV), self-efficacy (MV) and academic performance (DV), showed that teacher evaluative feedback is a big source that enhances students' self-efficacy which is pivotal for their academic performance. The same results were drawn from the study of Albert Bandura (1997), Chan and Lam (2010) and Mehregan and Seresht (2014). However, $\mathrm{H}_{2}$ (b) corrective feedback (IV) and self-efficacy (MV), $(t=1.097, p=0.273)$ have statistically assumed insignificance mediating relationship in overall model. Data did not support the mediating role of teacher corrective feedback and self-efficacy. This result does not support the theoretical and empirical studies conducted by Schunk and Zimmerman (1997), Koksal et al. (2018) and Winstone et al. (2019). The possible reasons for this result is due to inappropriate way and manner of providing corrective feedback in the classroom, students feeling shy and uncomfortable when teachers rectify their mistakes and errors in the classroom in front of their colleagues or fellows. They feel this corrective feedback as a source that exposes their failure or weaknesses in front of other students. The literature from Krashen (1982) strengthens this assumption as he explains that corrective feedback reduces students' motivational level and causes students' anxiety. Truscott (2004) pointed out that teachers must understand how to reflect on the mistakes or errors made with students. Hence, data from present study could not perceive teachers' corrective feedback as a positive source that develop students' self-efficacy beliefs.

\section{Conclusion}

The present study was conducted to investigate the impact of teachers' constructive, corrective, and evaluative feedback on students' academic performance and the mediating role of self-efficacy. Study was limited to three areas of teachers' feedback including constructive, corrective and evaluative feedback which are practiced by teachers to students during teaching and learning process. Feedback from the teachers encourages students to be more active and participative in class activities. It also assists students in adopting and processing the task assigned by the teachers. It helps to elevate the students' self-esteem, and helps in providing better guideline to the students for their academic career. This study investigates the data in depth and explores that teacher feedback in the form of constructive, corrective, and evaluative are very crucial ingredients to raise undergraduate students' academic performance during the academic period. The study also explored the mediating role of students' self-efficacy between teachers' constructive, corrective, evaluative feedback, and students' academic performance. The results reveal 
that teachers' constructive and evaluative feedback increase students' self-efficacy that encourage them to work hard for high academic achievement. Moreover, data of the study could not measure the positive and productive impact of corrective feedback in enhancing students' self-efficacy. It is thus recommended that university administrations arrange faculty professional development sessions at university level to develop the quality of constructive, corrective, and evaluative feedback. Teachers at university level need to provide constructive and evaluative feedback to their students in order to motivate undergraduate students for better academic performance. While providing corrective feedback, university faculty members need to be careful while giving oral or written comments regarding students' mistakes or errors. Sometimes, some students feel shy and uncomfortable, if teachers share their mistakes or errors in the classroom in front of their class fellows. 


\section{References}

Ahmad, I., Saeed, M., \& Salam, M. (2013). Effects of Corrective Feedback on Academic Achievement of Students: Case of Government Secondary Schools in Pakistan. International Journal of Science and Research, 2(1), 36-40.

Ahmad, A., \& Safaria, T. (2013). Effects of self-efficacy on students' academic performance. Journal of Educational, Health and Community Psychology, 2(1), 22-29.

Ahmed, I., Thomas, M., \& Hamid, S. (2020). Improving reading comprehension skill through interactive reading strategies of grade $10^{\text {th }}$ students at public secondary school. Pakistan Journal of Educational Research, 3(2).

Akkuzu, N. (2014). The role of different types of feedback in the reciprocal interaction of teaching performance and self-efficacy belief. Australian Journal of Teacher Education, 39(3), 3.

Arbabisarjou, A., Zare, S., Shahrakipour, M., \& Ghoreishinia, G. (2016). Relationship between Self-Efficacy and Academic Achievement of Zahedan Medical Sciences Students in 2016. International Journal of Medical Research \& Health Sciences, 5(7), 349-353.

Aston L, Hallam P (2011) Successful Mentoring in Nursing. Learning Matters, Exeter.

Awang, Z., Lim, S. H., \& Zainudin, N. F. S. (2018). Pendekatan mudah SEM: Structural Equation Modelling. Selangor: MPWS Rich Publication

Bandura, A. (2001). Social cognitive theory: An agentic perspective. Annual review of psychology, 52(1), 1-26.

Bandura, A. (1982). Self-efficacy mechanism in human agency. American psychologist, 37(2), 122.

Bandura, A. (1997). Self-efficacy: The exercise of control. New York: W. H. Freeman.

Cervelló, E. M., Escartí, A., \& Guzmán, J. F. (2007). Youth sport dropout from the achievement goal theory. Psicothema, 65-71.

Chandler, J. (2003). The efficacy of various kinds of error feedback for improvement in the accuracy and fluency of L2 student writing. Journal of second language writing, 12(3), 267-296.

Cáceres Aravena, R. (2015). The impact of the use of the Corrective Feedback perceived by EFL teachers on students oral production (Doctoral dissertation, Universidad Andrés Bello).

Chan, J. C., \& Lam, S. F. (2010). Effects of different evaluative feedback on students' selfefficacy in learning. Instructional Science, 38(1), 37-58. 
Du Toit, E. (2012). Constructive feedback as a learning tool to enhance students' selfregulation and performance in higher education. Perspectives in Education, 30(2), 3240 .

Dogan, U. (2015). Student engagement, academic self-efficacy, and academic motivation as predictors of academic performance. The Anthropologist, 20(3), 553-561.

Donche, V., Coertjens, L., Vanthournout, G., \& Van Petegem, P. (2012). Providing constructive feedback on learning patterns: an individual learner perspective. Reflecting education, 8(1), 114-132.

Duffy, K. (2013). Providing constructive feedback to students during mentoring. Nursing Standard (through 2013), 27(31), 50.

Dupret, A. R. (2016). The Effects of Evaluative Feedback on Novel-Task Self-Efficacy and Future Performance (Doctoral dissertation).

Erlam, R., Ellis, R., \& Batstone, R. (2013). Oral corrective feedback on L2 writing: Two approaches compared, System, 41, 257-268.

Fornell, C., \& Larcker, D. F. (1981). Structural equation models with unobservable variables and measurement error: Algebra and statistics.

Gold, A. H., Malhotra, A., \& Segars, A. H. (2001). Knowledge management: an organizational capabilities perspective. Journal of Management Information Systems, 18(1), 185-214.

Glickman, C.D. (2002). Leadership for learning: How to help teachers succeed. Alexandria, VA:

Association for Supervision and Curriculum Development

Hafeez, K., \& Wahaj, A. (2014). Feedback in Pakistan's Medical \& Dental Education System Feedback in Pakistan's Medical \& Dental Education System. J Pak Dent Assoc, 23, 175-8.

Hair, J. F., Ringle, C. M., \& Sarstedt, M. (2013). Partial least squares structural equation modeling: Rigorous applications, better results and higher acceptance. Long range planning, 46(1-2), 1-12.

Hair, J. F., Risher, J. J., Sarstedt, M., \& Ringle, C. M. (2019). When to use and how to report the results of PLS-SEM. European Business Review.

Hair, J. F., Rishe, J. J., Sarsted, M., \& Ringle, C. M. (2018). When to use and how to report the results of PLS-SEM. European Business Review, 31(1), 2-24.

Hattie, J., \& Timperley, H. (2007). The power of feedback. Review of educational research, 77(1), 81-112.

Hamid, Y., \& Mahmood, S. (2010). Understanding constructive feedback: a commitment between teachers and students for academic and professional development. J Pak Med Assoc, 60(3), 224-7. 
Henseler, J., Ringle, C. M., Sarstedt, M. (2015). A New Criterion for Assessing Discriminant Validity in Variance-based Structural Equation Modeling. Journal of the Academy of Marketing Science, 43(1),115-135. DOI 10.1007/s11747-014-0403-8

Honicke, T., \& Broadbent, J. (2016). The influence of academic self-efficacy on academic performance: A systematic review. Educational Research Review, 17, 63-84.

Jamalinesari, A., Rahimi, F., Gowhary, H., \& Azizifar, A. (2015). The effect of teacher-written direct vs. indirect feedback on students' writing. Procedia Social and Behavioral Sciences, 192, 116-123.

Köseoglu, Y. (2015). Self-Efficacy and Academic Achievement--A Case from Turkey. Journal of Education and Practice, 6(29), 131-141.

Kashif, M., Ur Rahman, A., Mustafa, Z., \& Basharat, S. (2014). Pakistani Higher Degree students' Views of Feedback on Assessment: Qualitative study. The International Journal of Management Education, 12(2), 104-114.

Krashen, Stephen. Principles and Practice in Second Language Acquisition: Oxford Pergamon, 1982.

Karl, K. A., O'Leary-Kelly, A. M., \& Martocchio, J. J. (1993). The impact of feedback and selfefficacy on performance in training. Journal of Organizational Behavior, 14(4), 379-394.

Köksal, D., Özdemir, E., Tercan, G., Süleyman, G. Ü. N., \& BİLGİN, E. (2018). The relationship between teachers' written feedback preferences, self-efficacy beliefs and burnout levels. Journal of Language and Linguistic Studies, 14(4), 316-327.

Kolo, A. G., Jaafar, W. M. B. W., \& Ahmad, N. B. (2017). Relationship between academic selfefficacy believed of college students and academic performance. IOSR Journal of Humanities and Social Science (IOSR-JHSS), 22(1), 75-80.

Li, B., Li, H., Bai, Y., Kirschner-Schwabe, R., Yang, J. J., Chen, Y., ... \& Li, W. (2015). Negative feedback-defective PRPS1 mutants drive thiopurine resistance in relapsed childhood ALL. Nature medicine, 21(6), 563.

Mehregan, M., \& Jafari-Seresht, D. (2014). The Role of Teacher Feedback in Enhancing Leaner Self-efficacy and Motivation in Computer-assisted Environments. MEXTESOL Journal, 38(3), 1-16.

Mandhane, N., Ansari, S., Shaikh, T. P., \& Deolekar, S. (2015). Positive feedback: a tool for quality education in field of medicine. International Journal of Research in Medical Sciences, 3(8), 1868-1873.

Meral, M., Colak, E., \& Zereyak, E. (2012). The relationship between self-efficacy and academic performance. Procedia-Social and Behavioral Sciences, 46, 1143-1146.

Mueller, C. M., \& Dweck, C. S. (1998). Praise for intelligence can undermine children's motivation and performance. Journal of Personality and Social Psychology, 75, 33-52. 
Nyiramana, C. (2017). Constructive Feedback to Students: A Tool to Enhance Educational Quality. ZEP: Zeitschrift für Internationale Bildungsforschung und Entwicklungspädagogik, 40(2), 14.

Naintara, U.-e.-H. (2016). Feedback Practices and Accounting Students' Satisfaction. Pak. j. eng. technol. sci., 6, 23-49.

Ovando, M. N. (1994). Constructive feedback: A key to successful teaching and learning. International Journal of Educational Management.

Oluwatayo, J.A. \& Fatoba, J.O. (2010). Effect of evaluative feedback on performance and retention of secondary school students in biology. Journal of Education Science, 2(1):56-59 (2010)

Omer, A. A. A., \& Abdularhim, M. E. (2017). The criteria of constructive feedback: The feedback that counts. Journal of Health Specialties, 5(1), 45.

Pham, T. K. D. (2015). Different forms of corrective feedback and their effects on L2 students' writing accuracy: A case study. Asian Journal of Educational Research, 3(1).

Ran, Q., \& Danli, L. (2016). Teachers' Feedback on Students' Performance in a Secondary EFL Classroom. Proceedings of ClaSIC (242-254). Singapore: NUC Centre.

Ringle, C. M., Wende, S., \& Becker, J. M. (2015). SmartPLS 3 [computer software]. http://www. smartpls.com

Srichanyachon, N. (2012). Teacher written feedback for L2 learners' writing development.Silpakorn University Journal of Social Sciences, Humanities, and Arts, 12(1), 7-17.

Sarvestani, M. S., \& Pishkar, K. (2015). The effect of written corrective feedback on writing accuracy of intermediate learners. Theory and Practice in Language Studies, 5(10), 2046-2052.

Shahzadi, E., \& Ahmad, Z. (2011). A study on academic performance of university students. Recent Advances in Statistics, 255.

Sermsook, K., Liamnimitr, J., \& Pochakorn, R. (2017). The Impact of Teacher Corrective Feedback on EFL Student Writers' Grammatical Improvement. English Language Teaching, 10(10), 43-49.

Schunk, D. H., \& Zimmerman, B. J. (2007). Influencing children's self-efficacy and selfregulation of reading and writing through modeling. Reading \& writing quarterly, 23(1), 7-25.

Tiyuri, A., Saberi, B., Miri, M., Shahrestanaki, E., Bayat, B. B., \& Salehiniya, H. (2018). Research self-efficacy and its relationship with academic performance in postgraduate students of Tehran University of Medical Sciences in 2016. Journal of education and health promotion, 7. 
Truscott, J. (2004). Evidence and conjecture on the effects of correction: A response to Chandler. Journal of second language writing, 13(4), 337-343.

Westmacott, A. (2017). Direct vs. indirect written corrective feedback: Student perceptions. Medellin, 22(1), 17-32.

Wang, S. \& Wu, P. (2008). The role of feedback and self-efficacy on web-based learning: The social cognitive perspective. Computers and Education, 51, 1589-1598.

Wilbert, J., Grosche, M., \& Gerdes, H. (2010). Effects of evaluative feedback on rate of learning and task motivation: an analogue experiment. Learning Disabilities: $A$ Contemporary Journal, 8(2), 43-52.

Winstone, N. E., Hepper, E. G., \& Nash, R. A. (2019). Individual differences in self-reported use of assessment feedback: The mediating role of feedback beliefs. Educational Psychology, 1-19. 